\title{
Binding of Gaseous Fe(III)-Heme Cation to Model Biological Molecules: Direct Association and Ligand Transfer Reactions
}

\author{
Fausto Angelelli, Barbara Chiavarino, Maria Elisa Crestoni, \\ and Simonetta Fornarini \\ Department of Studies on Chemistry and Technology of Biologically Active Substances, University of Rome, \\ "La Sapienza," Rome, Italy
}

The binding of a variety of ligands with Fe(III)-heme ${ }^{+}$ion, prosthetic group of heme proteins, has been studied in the gas phase by ESI-FT-ICR mass spectrometry. The ligands have been selected among substrate molecules of heme proteins (e.g., NO, nitroso compounds) or among model compounds acting for the functional groups that are present in the protein backbone (e.g., amines, thioethers, nitriles, ketones, amides, etc.). Both the kinetic and the thermodynamic features of the addition reactions are reported. Fe(III)-heme ${ }^{+}$ions react faster with lone pair donor ligands as the reaction becomes increasingly thermodynamically favored (higher heme cation basicity of the ligand, $\mathrm{HCB}$, namely $-\Delta \mathrm{G}^{\circ}$ for the ligand addition reaction). In turn HCBs correlate in general with the gas phase basicity toward the proton of the various ligands. A ligand addition equilibrium is established with weaker ligands, methanol, acetonitrile and acetone, yielding absolute $\mathrm{HCB}$ values, whereas ligand transfer equilibriums allowed a scale of relative (and absolute) HCBs to be constructed. NO displays exceptional binding properties towards $\mathrm{Fe}(\mathrm{III})-$ heme $^{+}$, unrelated to the low gas phase basicity toward the proton of this molecule, which is clearly the basis for the paramount role of heme proteins in NO binding and regulation. (J Am Soc Mass Spectrom 2005, 16, 589-598) (c) 2005 American Society for Mass Spectrometry

$\mathrm{T}$ The iron-protoporphyrin-IX (heme) complex is the active core of heme proteins, a vast family of metalloproteins performing important biological functions, such as oxygen transport and activation, hydrogen peroxide disproportionation, electron transfer, detoxification of metabolites and xenobiotics, biosynthesis of steroids and lipids, and delivery of oligonucleotides [1, 2]. In the heme complexes the iron is bonded to the porphyrin macrocycle. The axial sites may be used to bind amino acid residues of the protein or to bind a substrate molecule. The coordination features of various molecules or functional groups to these axial sites are crucial for the biological function of the heme protein [3, 4]. Valuable information on the intrinsic binding properties of various ligands to both free and ligated metal ions can be obtained by Fourier transform ion cyclotron resonance (FT-ICR) mass spectrometry [5], amply used for gas phase studies of ligand association reactions and of organometallic ion chemistry in general [6-12]. Electrospray ionization (ESI) [13-

Published online March 5, 2005

Address reprint requests to Professor S. Fornarini, Dipartimento di Studi di Chimica e Tecnologia delle Sostanze Biologicamente Attive, Università di Roma "La Sapienza", Piazzale A. Moro 5, I-00185 Rome, Italy. E-mail: simonetta.fornarini@uniroma1.it
15] allows a gentle and sensitive tool for investigating biomolecular ions and as such it is used in the present work to obtain gaseous heme type ions, although various sources can be used to generate iron porphyrin ions in the gas phase [16, 17]. Based on ESI-FT-ICR [18] the present study reports on the association reactions of iron(III)-porphyrin ions (Fe(III)-heme ${ }^{+}$) with exemplary ligands chosen among volatile compounds belonging to different families of Lewis bases, such as amines, carbonyl compounds, ethers, nitriles, sulfides, and phosphoryl compounds. Most of the selected ligands provide models, either of the functional groups in the amino acid residues or of the substrates of heme proteins. In particular, histidine (a ligand with an $\mathrm{sp}^{2}$ nitrogen) and methionine (owning a $\mathrm{CH}_{3} \mathrm{SCH}_{2} \mathrm{CH}_{2}-$ group) are frequently found as axial ligands of the heme group in proteins. Simple biatomic molecules, $\mathrm{O}_{2}, \mathrm{CO}$, and $\mathrm{NO}$, whose biological activity is modulated by their binding to protein-bound heme [1, 2, 19, 20], have also been tested. In general, given the fundamental role of metalloporphyrins in catalysis, organic synthesis and biology, this study is aimed to provide kinetic and thermodynamic data on relevant heme interactions in the absence of any solvent or counterion. To this end ligand transfer equilibriums are established in order to 
obtain a relative order for the free energies of ligand binding to $\mathrm{Fe}(\mathrm{III})-\mathrm{heme}^{+}$ions (henceforth named heme cation basicity, HCB) at constant temperature (300 K). At the same time, the simple addition reactions of a single ligand molecule are examined (eq 1), seeking a neat association equilibrium that may allow an internal anchor for the HCB ladder.

$$
\mathrm{Fe}(\mathrm{III}) \text {-heme }{ }^{+}+\mathrm{L} \rightarrow \mathrm{Fe}(\mathrm{III}) \text {-heme(L) }{ }^{+}
$$

The gas phase heme cation basicity (HCB) is then defined as the Gibbs free energy associated with the ligand addition reaction (eq 1), where $\operatorname{HCB}(\mathrm{L})=$ $-\Delta G_{1}{ }^{\circ}$. Few studies have reported the attainment of a gas phase association equilibrium in the low pressure range (typically $10^{-9}-10^{-7}$ mbar) prevailing in a FT-ICR cell $[21,22]$. However, the ligand addition to Fe(III)heme $^{+}$ions may present a favorable case because the addition of NO to doubly protonated iron tetrapyridylporphyrin ions $\left(\mathrm{FeTPyrPH}_{2}^{2+}\right)$ has been found to respond to an association equilibrium (eq 2), displaying an increasing relative abundance of free $\mathrm{FeTPyrPH}_{2}^{2+}$ ions at higher temperature [23].

$$
\mathrm{FeTPyrPH}_{2}^{2+}+\mathrm{NO} \rightleftarrows \mathrm{FeTPyrPH}_{2}(\mathrm{NO})^{2+}
$$

In the same work, Ridge and coworkers have reported the NO binding energies to both Fe(II)- and Fe(III)porphyrin ions based on the modeling of the kinetics of radiative association/dissociation. Although the equilibrium measurement was considered to be the most reliable, the binding energies obtained by the various approaches for different iron-porphyrin ions were found to be comparable, suggesting that the NO association is not strongly dependent on details of the porphyrin ligand such as phenyl or pyridyl-substitution or different charge due to added protons. On these premises, it is possible that a HCB order obtained for $\mathrm{Fe}$ (III)-heme ${ }^{+}$ions may apply to iron-porphyrin ions in general.

\section{Experimental}

All experiments were performed with a Bruker Spectrospin FT-ICR mass spectrometer (Bruker Daltonics, Billerica, MA) equipped with a cylindrical infinity cell within a $4.7 \mathrm{~T}$ superconducting magnet updated to BioApex with an Analytica of Branford Inc. (Branford, CT) ESI source. Hemin chloride (Fe(III)-heme ${ }^{+} \mathrm{Cl}^{-}$) was purchased from Sigma-Aldrich (Milan, Italy). $\mathrm{NO}, \mathrm{O}_{2}$, $\mathrm{CO}, \mathrm{NH}_{3}$, and $\mathrm{CH}_{3} \mathrm{NH}_{2}$ were high purity gases from Matheson Gas Products Inc. (Newark, CA). All other chemicals were obtained from commercial sources and used without further purification. ESI of hemin chloride yielded gaseous $\mathrm{Fe}$ (III)-heme ${ }^{+}$ions at nominal $\mathrm{m} / \mathrm{z} 616$. A $10 \mu \mathrm{M}$ solution of hemin chloride in methanol was infused at $2 \mu \mathrm{l} \mathrm{min}{ }^{-1}$ with a syringe pump. A countercurrent flow of heated dry gas (nitrogen at $130^{\circ} \mathrm{C}$ ) was used to desolvate the ions. After an accumulation interval of $0.5 \mathrm{~s}$ in an rf-only hexapole, the heme ion population was pulsed into the ICR cell at room temperature $(300 \mathrm{~K})$. Because ESI formed ions are introduced into the cell, the inner ionizing filament is not used, thus avoiding poor temperature control attributable to temperature gradients. Any adverse effect due to the heated filament in the ICR cell may thus be excluded [24]. Fe(III)-heme ${ }^{+}$ions were selected using single radiofrequency pulses to eject few ions of minor intensity and quenched of any excess kinetic energy by an argon pressure pulse using a magnetic valve. The kinetic progress of the ligand addition and ligand exchange reactions was monitored by recording 5-20 averaged scans for each mass spectrum in series of runs corresponding to increasing reaction time. The ligand $\mathrm{L}$ (or ligands $\mathrm{L}_{1}$ and $\mathrm{L}_{2}$ ), was leaked at a stationary pressure in the range of $0.6 \times 10^{-8}-9.5 \times 10^{-7} \mathrm{mbar}$ by an individual inlet device at room temperature. In some experiments the kinetics were studied in the presence of an added inert bath gas (argon). The ligand addition reactions going to completion were treated according to the pattern of irreversible pseudo first order kinetics and pseudo first order rate constants $\left(\mathrm{k}_{\mathrm{obs}}\right)$ were obtained from the slope of the semilog decrease of reactant ion intensity versus reaction time. The pseudo first order rate constants divided by the substrate concentration gave the bimolecular rate constants $\left(k_{\exp }\right)$. The partial pressures of the neutrals were read from a Bayard-Alpert ionization gauge (Balzers S.P.A., Milan, Italy), calibrated using the rate constant value of $1.1 \times$ $10^{-9} \mathrm{~cm}^{3} \mathrm{~s}^{-1}$ for the reference reaction $\mathrm{CH}_{4}^{+\cdot}+\mathrm{CH}_{4} \rightarrow$ $\mathrm{CH}_{3}+\mathrm{CH}_{5}^{+}$, and corrected using individual response factors $[25,26]$. The estimated error that is typically associated with the bimolecular rate constants $( \pm 30 \%)$ is caused largely by the uncertainty of neutral pressure [27]. The kinetics of the ligand addition reactions were recorded normally at three different values of neutral pressure. The reaction efficiencies $(\Phi)$ were calculated as percent ratio of $k_{\text {exp }}$ relative to the collision rate constant $\left(\mathrm{k}_{\mathrm{c}}\right)$ calculated by the parameterized trajectory theory [28]. Dipole moments were obtained from current literature or calculated by AM1 semiempirical calculations using the Spartan program suite (Wavefunction, Inc., Irvine, CA). In few cases where the addition reaction did not proceed to the total disappearance of the reagent ion but the system came to a constant ratio of the abundances of reagent and product ion, the kinetics have been analyzed according to the pattern for a reversible reaction.

Ligand exchange equilibriums were established in the FT-ICR cell at constant pressures of two neutrals $\mathrm{L}_{1}$ and $L_{2}$ when the relative abundances of the adduct ions, namely the couple $\mathrm{Fe}(\mathrm{III})$-heme $\left(\mathrm{L}_{1}\right)^{+}$and $\mathrm{Fe}(\mathrm{III})$ heme $\left(L_{2}\right)^{+}$, reached a constant value. The ratio of ion intensities was always kept within a range of $1 / 15-15 / 1$ by appropriate choice of the relative pressures of $L_{1}$ and $\mathrm{L}_{2}$, which ensured a reliable determination of the relative amounts of the adduct ions. The equilibrium constants for the ligand exchange reactions, $\mathrm{K}$, were calcu- 
lated from the known ratio of the partial pressures of the ligands and the observed abundances of the adduct ions. Using the general equilibrium expression $\Delta \mathrm{G}^{\circ}=$ $-\mathrm{RT} \operatorname{lnK}$, the corresponding free energy changes were obtained. Ion ejection pulses allowed to start from either side of the equilibrium to check that the equilibrium constant value were confirmed. The equilibrium constant was proven to be invariant with respect to changes in the relative pressures of the neutrals.

\section{Results and Discussion}

\section{Kinetics of Ligand Association Reactions}

$\mathrm{Fe}(\mathrm{III})$-heme ${ }^{+}$ions undergo an association reaction when they are allowed to react with a variety of compounds in the cell of an FT-ICR mass spectrometer. Kinetic experiments were conducted on ESI formed $\mathrm{Fe}(\mathrm{III})$-heme ${ }^{+}$ions appearing as an isotopic cluster at $\mathrm{m} / z$ 616. Fe(III)-heme ${ }^{+}$ions yield an addition product (eq 1) when selected neutrals (L) are leaked into the cell at a constant pressure in the range of $6 \times 10^{-9}-9.5 \times$ $10^{-7}$ mbar. However, the specific features, namely the rate and the extent of the association reaction were found to be highly variable, depending on the neutral being tested. Several sampled ligands display an addition reaction ending with the complete formation of the $\mathrm{Fe}(\mathrm{III})$-heme $(\mathrm{L})^{+}$adduct ion. Figure 1 shows the time dependence of ion abundances for the association with $\mathrm{NO}$ and the neat exponential decay of the reagent ion. It is worthy of note that the $\mathrm{Fe}$ (III)-heme ${ }^{+}$ion abundance profile shows an induction time when the Fe(III)-heme ${ }^{+}$ ions are not quenched by unreactive collisions with argon. This induction time is attributable to translational excitation of the reagent ion resulting in a decreased efficiency for the exothermic, entropically disfavored addition reaction, as well documented in gas phase ion chemistry. For this reason, all kinetic data are obtained from $\mathrm{Fe}(\mathrm{III})-\mathrm{heme}^{+}$ions that are preliminarily submitted to collisional quenching using a pulse of Ar.

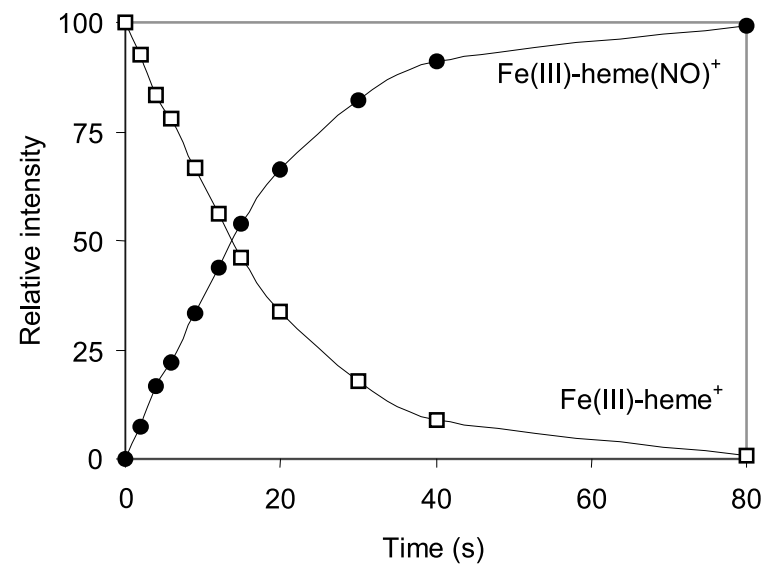

Figure 1. Time dependence of the relative ion abundances when $\mathrm{Fe}(\mathrm{III})-\mathrm{heme}^{+}$ions, thermalized by pulsed-in argon buffer gas, are allowed to react in the presence of $1.6 \times 10^{-7} \mathrm{mbar}$ NO.

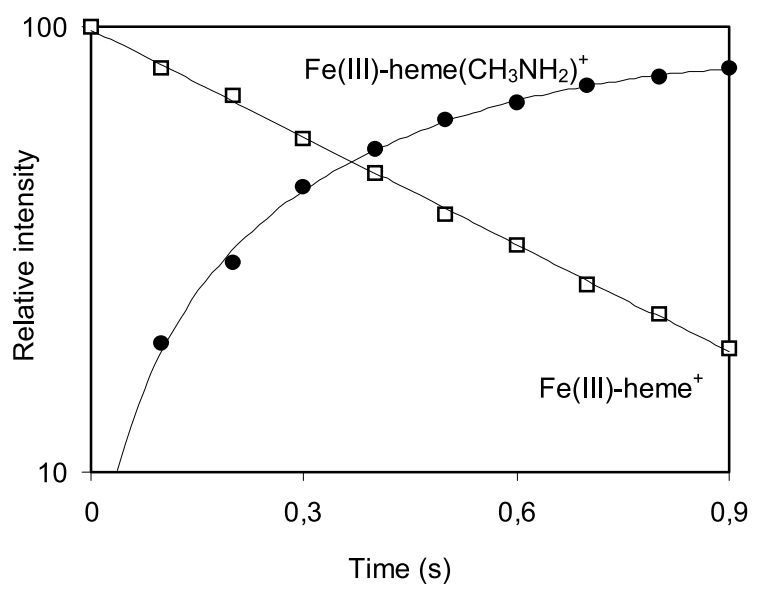

Figure 2. Semilogarithmic plot of the relative ion abundances versus time for the reaction of $\mathrm{Fe}(\mathrm{III})-$ heme $^{+}$with $2.2 \times 10^{-7} \mathrm{mbar}$ $\mathrm{CH}_{3} \mathrm{NH}_{2}$.

The addition reactions going to completion are found to obey pseudo first order kinetics because of the constant pressure of $\mathrm{L}$ in each set of kinetic experiments, as shown by the linear semilogarithmic plot of the temporal evolution of the intensity of the reactant $\mathrm{Fe}(\mathrm{III})-$ heme $^{+}$ion. A typical kinetic plot is shown in Figure 2, illustrating the time dependence of ion abundances for the $\mathrm{Fe}(\mathrm{III})$-heme ${ }^{+}$reaction with $\mathrm{CH}_{3} \mathrm{NH}_{2}$. The time constant of the process depends on the concentration of L. The overall second order kinetics of the addition reaction clearly emerge from the linear dependence of the pseudo first order rate coefficient $\left(\mathrm{k}_{\mathrm{obs}}\right)$ with respect to the concentration of $\mathrm{L}$, expressed as the partial pressure in mbar. The slope of linear plots, such as the one shown in Figure 3 for the $\mathrm{Fe}(\mathrm{III})$ heme ${ }^{+}$reaction with $\mathrm{CH}_{3} \mathrm{NH}_{2}$, yields the second order rate constant, $\mathrm{k}_{\exp }\left(\mathrm{k}_{\mathrm{obs}}=\mathrm{k}_{\exp }[\mathrm{L}]\right)$. The $\mathrm{k}_{\exp }$ values are normalized by the collisional rate constant to give the reaction efficiencies, also reported in Table 1 . Under the prevailing experimental conditions, the $\mathrm{Fe}(\mathrm{III})$ heme ${ }^{+}$reaction is limited to the addition of just one

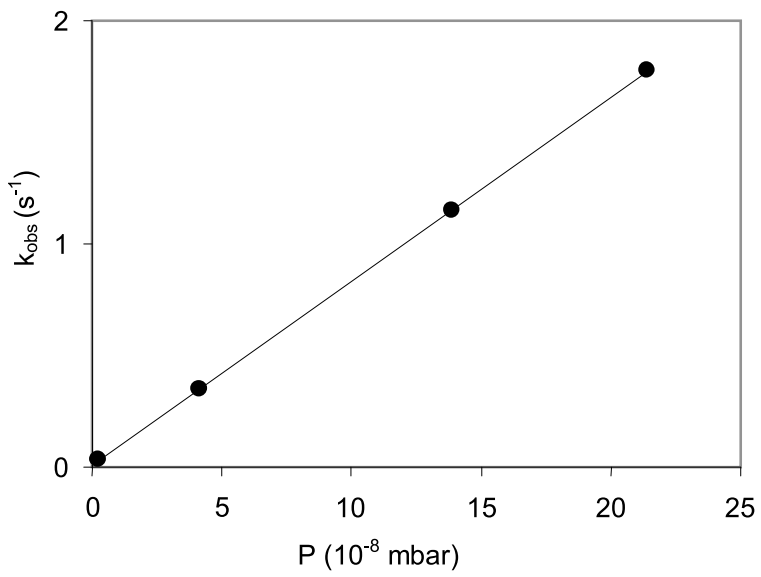

Figure 3. Pseudo-first order rate constants $\left(\mathrm{k}_{\mathrm{obs}}\right)$ for the $\mathrm{Fe}(\mathrm{III})$ heme ${ }^{+}$reaction with $\mathrm{CH}_{3} \mathrm{NH}_{2}$ plotted versus pressure of $\mathrm{CH}_{3} \mathrm{NH}_{2}$ in units of $10^{-8} \mathrm{mbar}$. 
Table 1. Rate constants and reaction efficiencies for the reactions of $\mathrm{Fe}(\mathrm{III})$-heme ${ }^{+}$with ligands (L) leading to complete formation of an adduct ion

\begin{tabular}{llcr}
\hline \multicolumn{1}{c}{$\mathrm{L}$} & $\mu(\mathrm{D})^{\mathrm{a}}$ & $\mathrm{k}_{\text {exp }}^{\mathrm{b}, \mathrm{c}}$ & $\Phi^{\mathrm{d}}$ \\
\hline \hline $\mathrm{NH}_{3}$ & 1.5 & 0.34 & 2.0 \\
$\mathrm{NO}$ & 0.16 & 0.22 & 3.0 \\
$\left(\mathrm{CH}_{3}\right)_{2} \mathrm{~S}$ & 1.5 & 0.94 & 7.0 \\
$\left(\mathrm{CH}_{3}\right)_{2} \mathrm{NNO}$ & 4.2 & 3.0 & 13.6 \\
Tetrahydrofuran & 1.6 & 1.8 & 14.4 \\
$\mathrm{CH}_{3} \mathrm{NH}_{2}$ & 1.3 & 3.6 & 27.2 \\
$\left(\mathrm{CH}_{3} \mathrm{O}\right)_{2} \mathrm{PO}(\mathrm{H})$ & 2.6 & 8.0 & 60.9 \\
$\mathrm{pyridine}$ & 2.2 & 9.0 & 64.1 \\
$\mathrm{CH}_{3} \mathrm{CON}(\mathrm{CH})_{2}$ & 3.8 & 13.1 & 76.6 \\
$\left(\mathrm{CH}_{3} \mathrm{O}\right)_{3} \mathrm{PO}$ & 3.0 & 10.9 & 84.2 \\
$\left(\mathrm{C}_{2} \mathrm{H}_{5} \mathrm{O}\right)_{3} \mathrm{P}$ & 2.3 & 13.0 & 97.5 \\
\hline
\end{tabular}

aUnits of debye.

bPhenomenological rate constants in units of $10^{-10} \mathrm{~cm}^{3}$ molecule $\mathrm{s}^{-1}$, at the temperature of the FT-ICR cell of $300 \mathrm{~K}$. The estimated error affecting the rate constant values is $\pm 30 \%$. The internal consistency of the data is within $\pm 10 \%$.

'The following neutrals failed to form adducts when allowed to react with Fe(III)-heme ${ }^{+}$ions: $\mathrm{CO}, \mathrm{O}_{2}, \mathrm{CH}_{3} \mathrm{C} \equiv \mathrm{CH}, \mathrm{C}_{6} \mathrm{H}_{6}, \mathrm{H}_{2} \mathrm{O}, \mathrm{H}_{2} \mathrm{~S}, \mathrm{C}_{2} \mathrm{H}_{5} \mathrm{ONO}$, $\mathrm{SO}_{2}$.

${ }^{\mathrm{d}} \Phi=\mathrm{k}_{\text {exp }} / \mathrm{k}_{\text {coll }} \times 100$

ligand molecule. The association of Fe(III)-heme $(\mathrm{L})^{+}$ with a second ligand molecule has been observed only in the case of $\left(\mathrm{C}_{2} \mathrm{H}_{5} \mathrm{O}\right)_{3} \mathrm{P}$, the ligand showing the highest reactivity towards association among the selected compounds.

Whereas association reactions of multiply ligated metal ions are quite common, even at the low operating pressures of ICR, a question rises about the mechanism allowing the addition products to form and to be stabilized with respect to back dissociation. In the general scheme for the association of an ion, $\mathrm{M}^{+}$, (corresponding to $\mathrm{Fe}(\mathrm{III})-\mathrm{heme}^{+}$in the present study) with a neutral molecule, L, an excited intermediate complex $\left[\mathrm{ML}^{+}\right]^{*}$ is primarily formed (eq 3 ) which may undergo rapid unimolecular decay $\left(k_{b}\right)$ if the energy released in the complex formation is not dissipated but remains stored within $\left[\mathrm{ML}^{+}\right]^{*}$. Stabilization of the complex may occur if this excess energy is dissipated either by radiative emission $\left(\mathrm{k}_{\mathrm{r}}\right)$ or by collision with a third body $\left(\beta k_{c}[L]\right)$ [29-31], where the role of the third body in eq 3 may be performed not only by $L$ but also by any other unreactive neutral present in cell.

$$
\mathrm{M}^{+}+\underset{\mathrm{k}_{\mathrm{b}}}{\stackrel{\mathrm{k}_{\mathrm{f}}}{\rightleftarrows}}\left[\mathrm{ML}^{+}\right]^{*} \underset{\beta \mathrm{k}_{\mathrm{c}}[\mathrm{L}]}{\stackrel{\mathrm{k}_{\mathrm{r}}}{\longrightarrow}} \mathrm{ML}^{+}
$$

The collisional stabilization route to $\mathrm{ML}^{+}$involves an overall termolecular process that should result in a pressure dependent behavior of $k_{\exp }$ [29-31]. In several association reactions involving relatively small-sized ions and neutrals the analysis of the pressure dependence of $k_{\text {exp }}$ has allowed the evaluation of the individual rate coefficients for the elementary steps of eq 3 [22, 32]. However, in the present case a constant value of $\mathrm{k}_{\exp }$ in the pressure range explored is verified for the $\mathrm{Fe}$ (III)-heme ${ }^{+}$association reactions with the tested li- gands. Incidentally, this behavior is consistent with the linearity of the plots of $k_{o b s}$ versus $P(L)$, such as the one shown in Figure 3. Alternatively, any pressure dependence of $k_{\text {exp }}$ should become evident when viewing the individual values as a function of the ligand pressure as displayed in Figure 4 for the NO reaction. The invariance of $k_{\exp }$ with respect to the ligand pressure is consistent with data points seemingly dispersed about a common average value $\left(\mathrm{k}_{\exp }=2.2 \times 10^{-11} \mathrm{~cm}^{3}\right.$ molecule $^{-1} \mathrm{~s}^{-1}$ for the NO reaction illustrated in Figure 4). Also the presence of an added inert bath gas (Ar) does not seem to affect $k_{\exp }$ as shown by the unchanged value that is obtained when the addition reaction is run at the same ligand pressure but in the presence of $\mathrm{Ar}$ making the total pressure equal to $5 \times 10^{-7} \mathrm{mbar}$ (empty squares in Figure 4). Routinely, $\mathrm{k}_{\exp }$ is obtained from the averaged value of $\mathrm{k}_{\mathrm{obs}} /[\mathrm{L}]$ within each set of kinetics, run at different pressures of the selected ligand. The values, obtained in this way, of $\mathrm{k}_{\exp }$ for addition reactions going to completion are reported in Table 1.

When one examines few other compounds, namely methanol, acetonitrile, and acetone, the association reaction of $\mathrm{Fe}(\mathrm{III})$-heme ${ }^{+}$does not proceed to completion. Free $\mathrm{Fe}(\mathrm{III})-\mathrm{heme}^{+}$ions remain even at long reaction times. The presence of an unreactive fraction of ions at a given $\mathrm{m} / \mathrm{z}$ value may be explained by a mixture of isomers, differing in their reactivity with the selected neutral. In many cases where bimodal rate behavior was observed, the analysis of kinetic data has given quantitative information not only on the reactivity of isomeric ions in a mixture but also on the proportion of each isomer [33, 34]. However, the relative amount of isomeric species (or, possibly, different electronic states of $\mathrm{Fe}(\mathrm{III})$-heme ${ }^{+}$ions), one of them being unreactive with the selected ligand, should be invariant with the ligand pressure. This is in contrast to the dependence on the ligand pressure displayed by the free and adduct

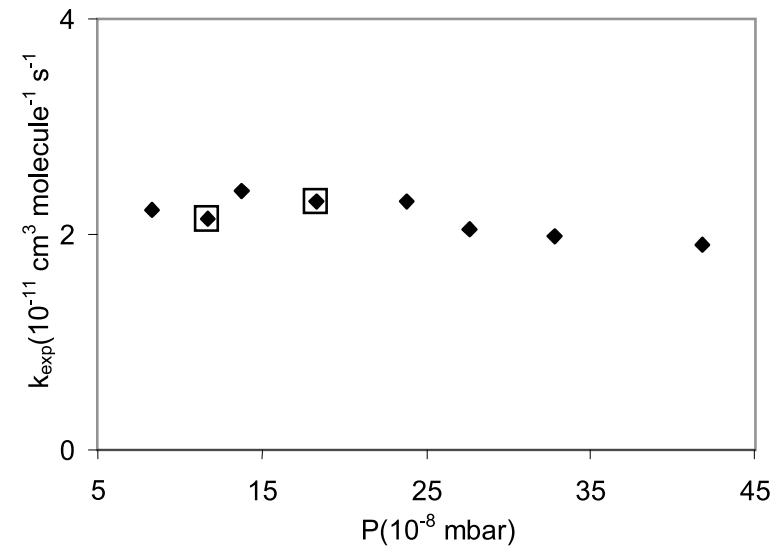

Figure 4. Plot of the apparent rate constant for the formation of the $\mathrm{Fe}(\mathrm{III})$-heme $(\mathrm{NO})^{+}$complex versus pressure of $\mathrm{NO}$ in units of $10^{-8}$ mbar. Empty squares refer to kinetics run in the presence of argon making the total pressure equal to $5 \times 10^{-7} \mathrm{mbar}$. As shown by the unchanged value of $k_{\text {exp }}$, the added bath gas does not affect the reaction rate constant. 


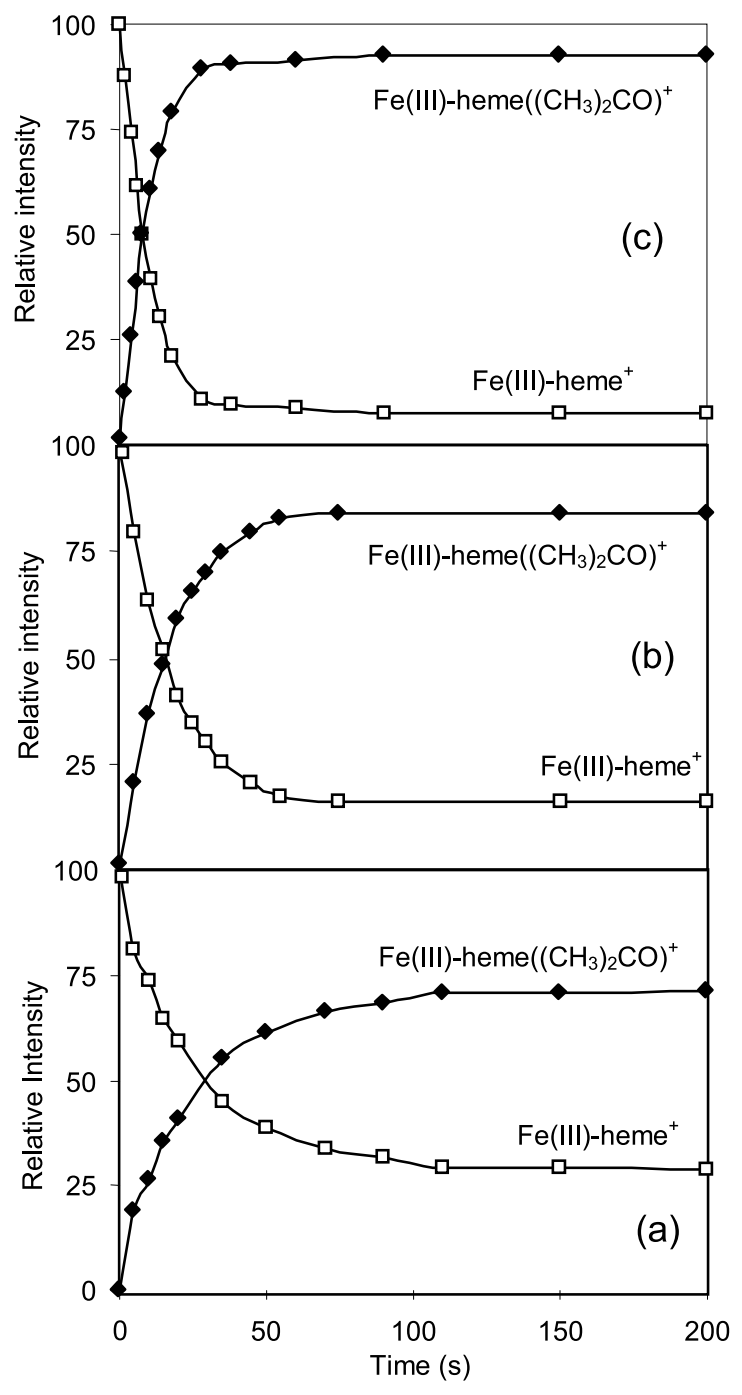

Figure 5. Time dependence of ion abundances for the Fe(III)heme $^{+}$ion reaction with acetone at $5.2 \times 10^{-8} \operatorname{mbar}(\mathbf{a}), 8.7 \times 10^{-8}$ mbar (b), $2.1 \times 10^{-7}$ mbar (c).

ion intensity ratio when the kinetic process has attained stationary concentrations. Figure $5 a, b$, and c shows the plots of ion intensities versus time for the reaction of $\mathrm{Fe}(\mathrm{III})$-heme ${ }^{+}$with acetone at three different pressure values. The residual fraction of $\mathrm{Fe}(\mathrm{III})-\mathrm{heme}^{+}$ions decreases with increasing acetone pressure as expected if the association reaction is reaching a state of equilibrium shifting in favor of the adduct ion when the ligand pressure is higher. The reaction apparently responds to the kinetic pattern of a reversible pseudo first order reaction (eq $\left.1^{\prime}\right)$.

$$
\mathrm{Fe}(\mathrm{III})-\mathrm{heme}^{+}+\underset{\mathrm{k}_{-1}}{\stackrel{\mathrm{k}_{1}}{\rightleftarrows}} \mathrm{Fe}(\mathrm{III})-\text { heme(L) }{ }^{+}
$$

Hence, the time evolution of the reactant ion intensity (I) has been treated according to eq 4 , where $\mathrm{I}_{0}$ and $\mathrm{I}_{\mathrm{e}}$ are the initial and equilibrium ion intensity, respectively.

$$
\begin{aligned}
& \ln \left[\left(\mathrm{I}_{0}-\mathrm{I}_{\mathrm{e}}\right) /\left(\mathrm{I}-\mathrm{I}_{\mathrm{e}}\right)\right]=\mathrm{k}_{\mathrm{obs}} \mathrm{t} \\
& \mathrm{k}_{\mathrm{obs}}=\mathrm{k}_{1}+\mathrm{k}_{-1}
\end{aligned}
$$

The overall rate constant for the approach to equilibrium $\left(k_{o b s}\right)$, given by the sum of the constants for the forward and reverse directions, $\mathrm{k}_{1}$ and $\mathrm{k}_{-1}$, respectively, has been obtained from the slope of the semilogarithmic plot of $\left[\left(\mathrm{I}_{0}\right.\right.$ $\left.-\mathrm{I}_{\mathrm{e}}\right) /\left(\mathrm{I}-\mathrm{I}_{\mathrm{e}}\right)$ ] versus time. The $\mathrm{k}_{\mathrm{obs}}$ values, obtained in this way, are listed in Table 2 summarizing the kinetic data for methanol, acetonitrile, and acetone. The $\mathrm{k}_{\mathrm{obs}}$ values for each series have been analyzed with regard to their dependence on the ligand pressure, assuming $k_{1}$ to be a pseudo first order rate constant $\left(\mathrm{k}_{1}=\mathrm{k}_{\text {exp }, 1}[\mathrm{~L}]\right)$, as found in the case of the association reactions going to completion. In this way, linear plots are obtained as shown by the example in Figure 6 describing the acetone reaction, the one most studied experimentally. The least squares fitting affords $\mathrm{k}_{\text {exp, } 1}$ and $\mathrm{k}_{-1}$ from the slope and the intercept, respectively, whose values are listed in Table 3 . The $k_{\text {exp }, 1}$ values have been used to derive the reaction efficiency $(\Phi)$, extending the scale reported in Table 1. Alternatively, the $\mathrm{k}_{1}$ and $\mathrm{k}_{-1}$ rate constants were obtained by fitting the experimental data to the kinetic scheme of eq $1^{\prime}$ using the program KinFit [35] and the ensuing values $\left(\mathrm{k}_{1}^{\mathrm{KF}}\right.$ and $\mathrm{k}_{-1}^{\mathrm{KF}}$, respectively) are also listed in Table 2 . The dependence of $\mathrm{k}_{1}^{\mathrm{KF}}$ on the ligand pressure, analyzed according to $\mathrm{k}_{1}^{\mathrm{KF}}=$ $\mathrm{k}_{\text {exp }, 1}^{\mathrm{KF}}[\mathrm{L}]$, yields values of $\mathrm{k}_{\exp , 1}^{\mathrm{KF}}$ which are reported together with the averaged $\mathrm{k}_{-1}^{\mathrm{KF}}$ values in Table 3 for comparison purposes.

\section{Ligand Association and Ligand Transfer Equilibriums}

Whereas an association equilibrium requires a fast thermal equilibration of "hot" addition complexes, which may have gained the total amount of the ionneutral binding energy as energy in excess with respect to thermal average, ligand transfer equilibriums involving only modest enthalpy changes are routinely established and studied in FT-ICR mass spectrometry, yielding valuable thermodynamic data. The thermodynamic features for the binding of $\mathrm{Fe}(\mathrm{III})-\mathrm{heme}^{+}$ions to a variety of neutrals have thus been approached by ligand exchange equilibriums, aiming to obtain a relative scale of $\mathrm{HCB}$ values. Ligand transfer equilibriums (eq 5) have been characterized yielding the relative free energy for binding of $\mathrm{Fe}(\mathrm{III})-$ heme ${ }^{+}$to ligands $\mathrm{L}_{1}$ and $\mathrm{L}_{2}$.

$$
\text { Fe(III)-heme }\left(\mathrm{L}_{1}\right)^{+}+\mathrm{L}_{2} \rightleftarrows \mathrm{Fe}(\mathrm{III}) \text {-heme }\left(\mathrm{L}_{2}\right)^{+}+\mathrm{L}_{1}
$$

Based on the equilibrium expression, $\Delta \mathrm{G}_{5}{ }^{\circ}=-\mathrm{RT} \mathrm{K}_{5}$, where $\Delta \mathrm{G}_{5}^{\circ}=\mathrm{HCB}\left(\mathrm{L}_{1}\right)-\operatorname{HCB}\left(\mathrm{L}_{2}\right)$, and using combinations of $\mathrm{L}_{1}$ and $\mathrm{L}_{2}$ of progressively increasing affinity for $\mathrm{Fe}(\mathrm{III})$-heme ${ }^{+}$, a scale of corresponding $\delta(\mathrm{HCB})$ values at $300 \mathrm{~K}$ has been constructed. The individual ligand couples that were allowed to compete for Fe(III)-heme ${ }^{+}$are shown in Table 4 , where the derived values of $K_{5}$ and $\Delta G_{5}{ }^{\circ}$ are listed. The final establishment of an equilibrium was ensured by checking the constancy of the ion intensity 
Table 2. Kinetic and equilibrium data for the reactions of Fe(III)-heme ${ }^{+}$with ligands (L) leading to a constant intensity ratio for the $\mathrm{Fe}(\mathrm{III})-\mathrm{heme}^{+}$ion and the adduct ion

\begin{tabular}{|c|c|c|c|c|c|c|}
\hline L & $\mathrm{P}^{\mathrm{a}}$ & $\mathrm{k}_{\mathrm{obs}} / \mathrm{s}^{-1}$ & $\mathrm{k}_{1}{ }^{\mathrm{KF}} / \mathrm{s}^{-1}$ & $\mathrm{k}_{-1}{ }^{\mathrm{KF}} / \mathrm{s}^{-1}$ & Int. ratio ${ }^{b}$ & $\mathrm{~K}_{1} / 10^{9 \mathrm{c}}$ \\
\hline $\mathrm{CH}_{3} \mathrm{OH}$ & 2.0 & 0.041 & 0.013 & 0.019 & 0.65 & 3.3 \\
\hline $\mathrm{CH}_{3} \mathrm{OH}$ & 2.9 & 0.045 & 0.018 & 0.017 & 1.0 & 3.5 \\
\hline $\mathrm{CH}_{3} \mathrm{OH}$ & 4.4 & 0.059 & 0.025 & 0.021 & 1.1 & 2.6 \\
\hline $\mathrm{CH}_{3} \mathrm{CN}$ & 1.8 & n.a. ${ }^{d}$ & n.a. ${ }^{d}$ & n.a. ${ }^{d}$ & 1.6 & 9.0 \\
\hline $\mathrm{CH}_{3} \mathrm{CN}$ & 2.1 & 0.058 & 0.039 & 0.018 & 2.1 & 10.2 \\
\hline $\mathrm{CH}_{3} \mathrm{CN}$ & 2.6 & 0.056 & 0.028 & 0.020 & 1.7 & 6.7 \\
\hline $\mathrm{CH}_{3} \mathrm{CN}$ & 3.6 & 0.087 & 0.062 & 0.020 & 3.1 & 8.6 \\
\hline $\mathrm{CH}_{3} \mathrm{CN}$ & 9.3 & 0.29 & 0.17 & 0.011 & 8.8 & 9.6 \\
\hline$\left(\mathrm{CH}_{3}\right)_{2} \mathrm{CO}$ & 0.52 & 0.038 & 0.031 & 0.013 & 2.4 & 46 \\
\hline$\left(\mathrm{CH}_{3}\right)_{2} \mathrm{CO}$ & 0.87 & 0.064 & 0.053 & 0.008 & 3.8 & 44 \\
\hline$\left(\mathrm{CH}_{3}\right)_{2} \mathrm{CO}$ & 0.88 & 0.063 & 0.048 & 0.008 & 5.3 & 60 \\
\hline$\left(\mathrm{CH}_{3}\right)_{2} \mathrm{CO}$ & 0.94 & n.a. ${ }^{d}$ & n.a. ${ }^{d}$ & n.a. ${ }^{d}$ & 4.6 & 49 \\
\hline$\left(\mathrm{CH}_{3}\right)_{2} \mathrm{CO}$ & 1.1 & 0.070 & 0.058 & 0.009 & 5.5 & 51 \\
\hline$\left(\mathrm{CH}_{3}\right)_{2} \mathrm{CO}$ & 1.4 & 0.078 & 0.058 & 0.010 & 5.3 & 39 \\
\hline$\left(\mathrm{CH}_{3}\right)_{2} \mathrm{CO}$ & 1.7 & 0.095 & 0.081 & 0.007 & 9.5 & 55 \\
\hline$\left(\mathrm{CH}_{3}\right)_{2} \mathrm{CO}$ & 2.1 & 0.106 & 0.086 & 0.007 & 12 & 58 \\
\hline
\end{tabular}

aLigand pressure in units of $10^{-7} \mathrm{mbar}$.

bI(Fe(III)-heme(L) $\left.{ }^{+}\right) /\left(\right.$(Fe(III)-heme $\left.{ }^{+}\right)$.

cStandard state 1 atm.

${ }^{d}$ n.a.: not available.

ratios after the kinetic progress of the association reaction of $\mathrm{Fe}(\mathrm{III})$-heme ${ }^{+}$with $\mathrm{L}_{1}$ and $\mathrm{L}_{2}$ was over and by selectively ejecting either $\mathrm{Fe}(\mathrm{III})$-heme $\left(\mathrm{L}_{1}\right)^{+}$or $\mathrm{Fe}(\mathrm{III})$ heme $\left(\mathrm{L}_{2}\right)^{+}$ions at equilibrium and then allowing the kinetics to proceed to a newly restored equilibrium. The so-obtained $\Delta \mathrm{G}_{5}{ }^{\circ}$ values cover a ca. $13 \mathrm{kcal} / \mathrm{mol}$ range of relative $\mathrm{HCB}$ values and are displayed graphically in Figure 7.

The ladder of relative $\mathrm{HCB}$ values can be used to derive absolute HCB values if at least one absolute reference value were available. In the kinetic study of the ligand association reactions reported in the previous section, several pieces of evidence concur to suggest that the addition reactions that do not reach completion, ending rather with measurable amounts of free and adduct ion in a time independent ratio, do reflect the attainment of an association equilibrium. Last but not least, a constant ion intensity ratio is verified when the ligand addition equilibrium is approached from both the forward and the reverse directions. An example is depicted in the experiment described in Figure 8. The final ion abundances that are observed when Fe(III)-heme ${ }^{+}$is allowed to react with acetone at $9.4 \times 10^{-8}$ mbar are shown in Figure 8a and can be compared with the ion abundance ratio that is obtained when the adduct ion at $m / z 674$ is selected in the FT-ICR cell and allowed to undergo partial dissociation at the same pressure of acetone (Figure $8 \mathrm{~b}$ ). The end ion intensity ratios (see Table 2 ) have been used to derive $\mathrm{K}_{1}$ values (eq 6) that are listed in the last column of Table 2.

$$
\mathrm{K}_{1}=\frac{\mathrm{I}\left(\mathrm{Fe}(\mathrm{III})-\text { heme }(\mathrm{L})^{+}\right)}{\mathrm{I}\left(\mathrm{Fe}(\mathrm{III})-\text { heme }^{+}\right) \times \mathrm{P}(\mathrm{L})}
$$

The averaged $K_{1}$ values and the derived $-\Delta G_{1}^{\circ}$ values are summarized in Table 5 . The reported $-\Delta \mathrm{G}_{1}{ }^{\circ}$ take on the meaning of $\mathrm{HCB}$ values for the three ligands responding to addition equilibriums. Differences between HCBs derived in this way can be tested for consistency with $\Delta \mathrm{G}_{5}{ }^{\circ}$ obtained from the ligand transfer equilibriums. The HCB difference between methanol and acetonitrile $\left(0.6 \mathrm{kcal} \mathrm{mol}^{-1}\right)$ is equal to $\Delta \mathrm{G}_{5}{ }^{\circ}$ for this pair of ligands and the HCB difference between acetonitrile and acetone $\left(1.0 \mathrm{kcal} \mathrm{mol}^{-1}\right)$ compares well with the corresponding $\Delta \mathrm{G}_{5}{ }^{\circ}$, equal to $0.8 \mathrm{kcal} \mathrm{mol}^{-1}$. This agreement provides further evidence that an association equilibrium is attained.

It may also be of interest to verify whether and to which extent the rate data obtained for the ligand association reactions are related to equilibrium parameters. To this end, columns 4 and 5 of Table 5 list the ratios of the rate constants for the forward and reverse

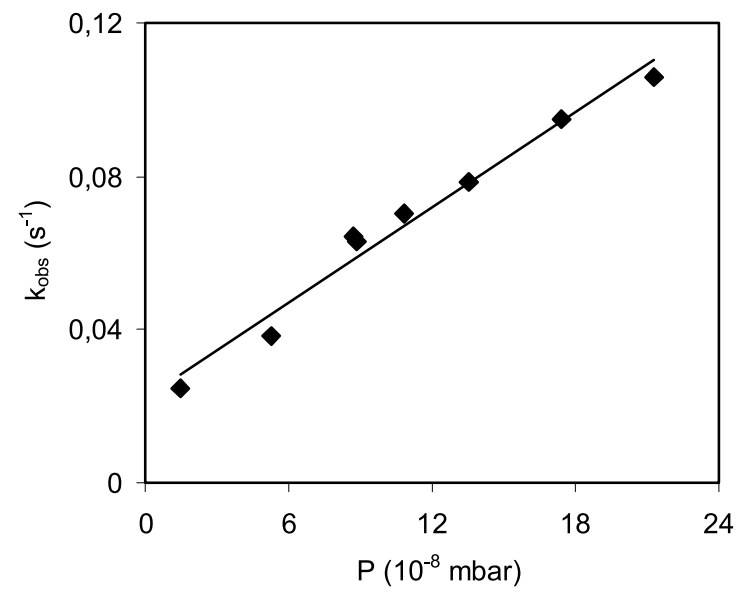

Figure 6. Plot of $\mathrm{k}_{\text {obs }}$ (eq 4) for the $\mathrm{Fe}(\mathrm{III})$-heme ${ }^{+}$ion reaction with acetone versus pressure of $\left(\mathrm{CH}_{3}\right)_{2} \mathrm{CO}$. The linear fit is interpreted by the equation $\mathrm{k}_{\mathrm{obs}}=\mathrm{k}_{\text {exp }, 1}[\mathrm{~L}]+\mathrm{k}_{-1}$. 
Table 3. Summary of kinetic data for the reactions of Fe(III)-heme ${ }^{+}$with ligands (L) leading to a constant intensity ratio for the $\mathrm{Fe}(\mathrm{III})-\mathrm{heme}^{+}$ion and the adduct ion

\begin{tabular}{lcccrrr}
\hline \multicolumn{1}{c}{$\mathrm{L}$} & $\mathrm{k}_{\exp , 1}{ }^{\mathrm{a}}$ & $\mathrm{k}_{-1} / \mathrm{s}^{-1}$ & $\mathrm{r}^{\mathrm{b}}$ & $\Phi^{\mathrm{c}}$ & $\mathrm{k}_{\exp , 1} \mathrm{KFa}^{\mathrm{c}}$ & $\mathrm{k}_{-1}{ }^{\mathrm{KF}} / \mathrm{s}^{-1}$ \\
\hline \hline $\mathrm{CH}_{3} \mathrm{OH}$ & $0.032 \pm 0.006$ & $0.025 \pm 0.005$ & 0.984 & 0.2 & $0.021 \pm 0.001$ & $0.019 \pm 0.002$ \\
$\mathrm{CH}_{3} \mathrm{CN}$ & $0.138 \pm 0.008$ & $0.024 \pm 0.011$ & 0.996 & 0.6 & $0.080 \pm 0.008$ & $0.018 \pm 0.004$ \\
$\left(\mathrm{CH}_{3}\right)_{2} \mathrm{CO}$ & $0.168 \pm 0.014$ & $0.024 \pm 0.005$ & 0.982 & 1.0 & $0.14 \pm 0.017$ & $0.009 \pm 0.002$ \\
\hline
\end{tabular}

In units of $10^{-10} \mathrm{~cm}^{3}$ molecule ${ }^{-1} \mathrm{~s}^{-1}$.

${ }^{b}$ Correlation coefficient for the least squares fit of $k_{\text {obs }}$ versus [L] $\left(k_{\text {obs }}=k_{\text {exp, } 1}[L]+k_{-1}\right)$.

${ }^{\mathrm{c}} \Phi=\mathrm{k}_{\mathrm{exp}, 1} / \mathrm{k}_{\text {coll }} \times 100$.

step of reaction 4, which, in the framework of Boltzmann-type kinetics, should yield the equilibrium constant for the process. The values that are obtained are not far from (in the case of methanol, quite close to) the $\mathrm{K}_{1}$ values obtained from the ion abundances at equilibrium.

The overall picture is consistent with an addition reaction attaining equilibrium under conditions implying that all species involved are in thermal equilibrium with the environment. Whereas this condition is assumed to hold at higher operative pressures, for example in helium buffer at $10^{-4}$ mbar in ion trap mass spectrometry (a recent example of ligand addition equilibriums to $\mathrm{Ni}(\mathrm{II})$ complexes is reported in ref [36]), the typically low pressure regime prevailing in FT-ICR requires careful consideration. In this pressure regime, energy exchange by collisions with a bath gas is slow and may not compete with faster processes. The possibility for an ionic reaction (both bimolecular addition reactions and unimolecular dissociation processes) to fulfill thermal equilibration with the surroundings by radiative exchange of IR photons increases with increasing size of the species and increasing vibrational modes $[29,31,37,38]$. In this respect, the Fe(III)-heme ${ }^{+}$ions are close to the lower size range for efficient thermal equilibration to occur, as estimated according to the "standard hydrocarbon" model. However, the heme group is characterized by the presence of strongly IR active modes, favoring rapid energy exchange with the background IR radiation field [39]. Incidentally, this feature is common to few ionic species that have been recognized to partake in association equilibriums in FT-ICR [21, 22]. When safely assessed, the occurrence of an association equilibrium may provide a reference value to be used as anchor to a ladder of ion transfer equilibriums. To this end, the low pressure conditions prevailing in FT-ICR mass spectrometry may give access to a range of association equilibriums that would be impossible to study at higher neutral pressure, being completely shifted to the product side [21]. A detailed analysis of the strongly coupled domains of pressure, binding energy, temperature and molecular size has predicted the frame for an association equilibrium to be established and observed in the FT-ICR mass spectrometer [21]. The critical balance of the various factors should allow: (1) a limited total number of collisions by the ions of interest with the bath gas to prevent diffusional loss out of the cell; (2) a reasonable amount of time required for the equilibrium to be established; (3) relative ion abundances falling well within the dynamic range of the technique, ensuring the reliable measurement of the ion intensity ratio; (4) an efficient energy equilibration mechanism. Ideally, at any stage of the forward and reverse step of the association reaction, the species involved should be thermally equilibrated with the ambient blackbody radiation field. Fast energy flow in the form of IR photons should efficiently cool the species undergoing association while heating to thermal average distribution the ion-ligand complex population potentially depleted in the high energy fraction due to the ions undergoing dissociation $[37,38]$. In this respect, as already pointed out, $\mathrm{Fe}(\mathrm{III})-\mathrm{heme}^{+}$may present a favorable case because of the molecular size (219 degrees of freedom) and because of very high radiative intensities due to polar groups like the carboxylic units. The gathered evidence, in particular the agreement between the ligand transfer free energies and the differences between HCB values obtained from the association reactions, provide strong indication that association equilibriums are indeed established.

Relying on the association equilibriums of Fe(III)heme $^{+}$ions with methanol, acetonitrile, and acetone

Table 4. Thermodynamic data for the ligand transfer reactions $\mathrm{Fe}(\mathrm{III})$-heme $\left(\mathrm{L}_{1}\right)^{+}+\mathrm{L}_{2} \rightarrow \mathrm{Fe}(\mathrm{III})$-heme $\left(\mathrm{L}_{2}\right)^{+}+\mathrm{L}_{1}$

\begin{tabular}{|c|c|c|c|}
\hline $\mathrm{L}_{1}$ & $\mathrm{~L}_{2}$ & $\mathrm{~K}_{5}{ }^{\mathrm{a}}$ & $-\Delta G_{5}{ }^{o b}$ \\
\hline $\mathrm{CH}_{3} \mathrm{OH}$ & $\mathrm{CH}_{3} \mathrm{CN}$ & 2.8 & 0.6 \\
\hline $\mathrm{CH}_{3} \mathrm{OH}$ & NO & 65 & 2.5 \\
\hline $\mathrm{CH}_{3} \mathrm{CN}$ & $\left(\mathrm{CH}_{3}\right)_{2} \mathrm{CO}$ & 3.4 & 0.8 \\
\hline $\mathrm{CH}_{3} \mathrm{CN}$ & $\mathrm{NH}_{3}$ & 90 & 2.7 \\
\hline$\left(\mathrm{CH}_{3}\right)_{2} \mathrm{CO}$ & NO & 12 & 1.5 \\
\hline $\mathrm{CH}_{3} \mathrm{CO}_{2} \mathrm{CH}_{3}$ & NO & 9.4 & 1.4 \\
\hline$\left(\mathrm{CH}_{3}\right)_{2} \mathrm{CO}$ & $\mathrm{NH}_{3}$ & 28 & 2.0 \\
\hline$\left(\mathrm{CH}_{3}\right)_{2} \mathrm{CO}$ & $\mathrm{ND}_{3}$ & 34 & 2.1 \\
\hline NO & $\left(\mathrm{CH}_{3}\right)_{2} \mathrm{NNO}$ & 100 & 2.8 \\
\hline NO & $\mathrm{NH}_{3}$ & 2.4 & 0.5 \\
\hline NO & $\left(\mathrm{CH}_{3}\right)_{2} \mathrm{~S}$ & 4.0 & 0.8 \\
\hline NO & THF & 28 & 2.0 \\
\hline$\left(\mathrm{CH}_{3}\right)_{2} \mathrm{~S}$ & THF & 18 & 1.7 \\
\hline THF & $\left(\mathrm{CH}_{3}\right)_{2} \mathrm{NNO}$ & 2.4 & 0.5 \\
\hline THF & $\mathrm{CH}_{3} \mathrm{NH}_{2}$ & 190 & 3.1 \\
\hline $\mathrm{CH}_{3} \mathrm{NH}_{2}$ & Pyridine & 130 & 2.9 \\
\hline$\left(\mathrm{CH}_{3} \mathrm{O}\right)_{2} \mathrm{PO}(\mathrm{H})$ & Pyridine & 11 & 1.4 \\
\hline Pyridine & $\mathrm{CH}_{3} \mathrm{CON}\left(\mathrm{CH}_{3}\right)_{2}$ & 3.3 & 0.7 \\
\hline Pyridine & $\left(\mathrm{CH}_{3} \mathrm{O}\right)_{3} \mathrm{PO}$ & 26 & 2.0 \\
\hline
\end{tabular}

aThe agreement between replicate measurements is within $\pm 20 \%$. bStandard deviation is $\pm 0.2 \mathrm{kcal} \mathrm{mol}^{-1}$. 


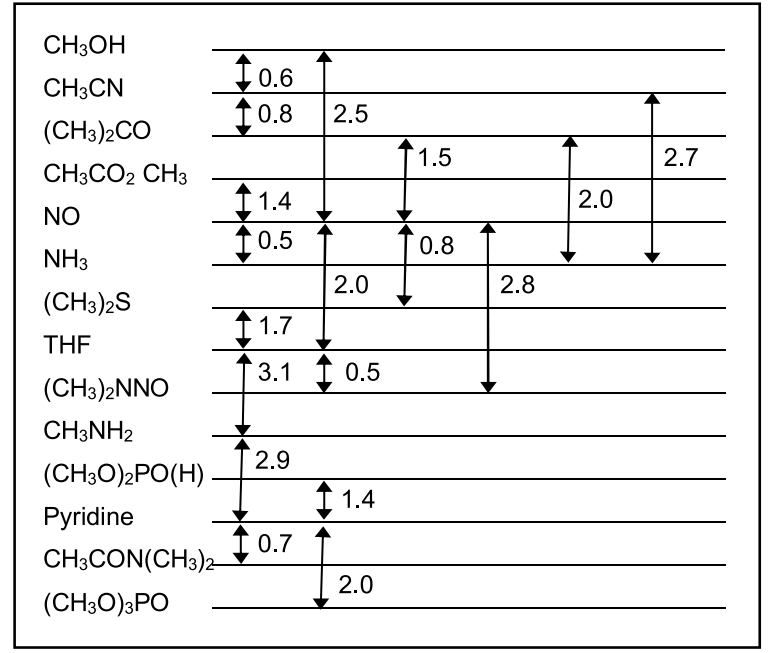

Figure 7. $\Delta \mathrm{G}_{5}{ }^{\circ}\left(\mathrm{kcal} \mathrm{mol}^{-1}, 300 \mathrm{~K}\right)$ ladder for the Fe(III)-heme ${ }^{+}$ transfer reactions between selected pairs of ligands. The values in the ladder correspond to HCB differences for each couple of ligands.

and reference $\mathrm{HCB}$ values obtained in this way, the $\Delta \mathrm{G}_{5}{ }^{\circ}$ data reported in Table 4 and illustrated in Figure 7 can be used to derive the HCB values of the selected ligands that are listed in Table 6. The range of absolute HCB values spans from $13.1 \mathrm{kcal} \mathrm{mol}^{-1}$ for the least associated neutral (methanol) to $26.1 \mathrm{kcal} \mathrm{mol}^{-1}$ for $\left(\mathrm{CH}_{3} \mathrm{O}\right)_{3} \mathrm{PO}$, the most strongly bound ligand. Among the entries in Table 6, the HCB value of $16.1 \mathrm{kcal} \mathrm{mol}^{-1}$ for $\mathrm{NO}$ is valuable, given the biological role of heme units binding to this ligand. We may use this value to obtain an estimated binding enthalpy, assuming that the association entropy $\Delta \mathrm{S}_{1}{ }^{\circ}$ is $-35 \mathrm{cal} \mathrm{mol}^{-1} \mathrm{~K}^{-1}$, approximately the translational entropy change, neglecting entropy changes due to the internal degrees of freedom of the complex relative to the free ion and ligand. In this way, a binding energy of $26.6 \pm 1.8 \mathrm{kcal}$ $\mathrm{mol}^{-1}$ is obtained, which is remarkably close to the value of $24.8 \pm 0.7 \mathrm{kcal} \mathrm{mol}^{-1}$ derived from the modeling of the radiative association kinetics [23].

\section{Kinetic and Thermodynamic Features of the Ligand Binding to $\mathrm{Fe}(\mathrm{III})-\mathrm{Heme}^{+}$Ions}

The sampled ligands are listed in Tables 1 and 3 according to their increasing efficiency values for the association reaction with $\mathrm{Fe}(\mathrm{III})-\mathrm{heme}^{+}$. The order is very nearly the same as the bonding free energies reported in Table 6. The observed positive trend is consistent with the predicted positive dependence of the association efficiency parameter with the binding energy $[29,31]$. The association efficiency parameter, measuring the ratio of the radiative stabilization to the redissociation rate constants of the excited adduct, becomes equal to $\Phi$ at low efficiencies, increasing with the binding energy for adduct ions of similar size. To a first approximation, the large iron-porphyrin moiety in $\mathrm{Fe}(\mathrm{III})$-heme $(\mathrm{L})^{+}$adducts makes the complexes similar in size and also in complex formation entropy and may explain the qualitative correlation between kinetic $(\Phi)$ and thermodynamic (HCB) data, at least in the low efficiency range.

The reported efficiencies vary from $97 \%$ for $\left(\mathrm{C}_{2} \mathrm{H}_{5} \mathrm{O}\right)_{3} \mathrm{P}$ down to $0.2 \%$ for $\mathrm{CH}_{3} \mathrm{OH}$, whereas the reaction with several other tested compounds (e.g., $\mathrm{CO}$, $\left.\mathrm{O}_{2}, \mathrm{CH}_{3} \mathrm{C} \equiv \mathrm{CH}, \mathrm{C}_{6} \mathrm{H}_{6}, \mathrm{H}_{2} \mathrm{O}, \mathrm{H}_{2} \mathrm{~S}, \mathrm{C}_{2} \mathrm{H}_{5} \mathrm{ONO}, \mathrm{SO}_{2}\right)$ is apparently too slow to be detected. The selected ligands provide models of the functional groups present on amino acid residues. For example, $\left(\mathrm{CH}_{3}\right)_{2} \mathrm{~S}$ is a model of the $\mathrm{CH}_{3} \mathrm{~S}\left(\mathrm{CH}_{2}\right)_{2}$-functionality of methionine, $\mathrm{CH}_{3} \mathrm{NH}_{2}$ is a primary amine mimicking the $\mathrm{NH}_{2}\left(\mathrm{CH}_{2}\right)_{4}$-end group of lysine, ketones, amides, and esters may be representative of the groups forming the backbone of the proteins. In addition, tetrahydrofuran (THF) has been chosen as model of the furanose portion of nucleotides. Acetonitrile, pyridine and amines possess a nitrogen atom in the $\mathrm{sp}, \mathrm{sp}^{2}$, and $\mathrm{sp}^{3}$ hybrid state, respectively. $\left(\mathrm{CH}_{3} \mathrm{O}\right)_{3} \mathrm{PO}$ is used as phosphoryl ligand (related to post-transcriptional modifications) and $\left(\mathrm{C}_{2} \mathrm{H}_{5} \mathrm{O}\right)_{3} \mathrm{P}$ as source of trivalent phosphorous. In the series of selected compounds $\mathrm{NO}$ and $\left(\mathrm{CH}_{3}\right)_{2} \mathrm{NNO}$ cover a special role due to their in-vivo interaction with the iron center of hemeproteins or as models of the active species in the metabolic pathway of carcinogenic nitrosamines, a process recognized to occur in ferric liver microsomal cytochrome P450 [40]. These ligands differ, however, for their binding mode, $\eta^{1}-\mathrm{N}$ for $\mathrm{NO}$ and $\eta^{1}-\mathrm{O}$ for $\left(\mathrm{CH}_{3}\right)_{2} \mathrm{NNO}$, as suggested by the crystal structure of a ferric bis-nitrosamine tetraphenylporphyrinato complex [41]. The fate of heme-nitrosyl and -nitrosamine adducts is possibly cross-related. In fact, some nitrosyl-iron-porphyrins have been found able to nitrosate secondary amines, yielding the corresponding carcinogenic nitrosamines [42]. In this respect hemebased compounds have been proposed as scavengers of noxious components $\left(\mathrm{NO}, \mathrm{NO}_{2}, \mathrm{CO}\right.$, nitrosocom-

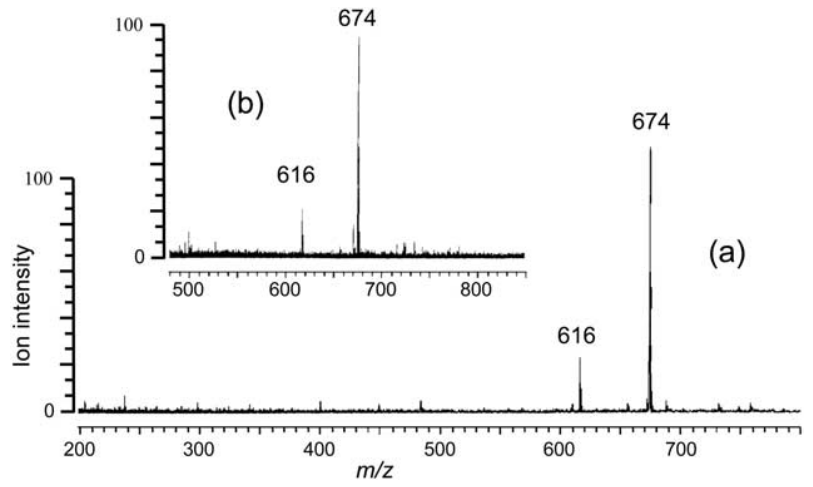

Figure 8. FT-ICR mass spectra showing the constant ratio of ion abundances that are observed when (a) mass selected Fe(III)heme $^{+}$ions $(\mathrm{m} / \mathrm{z} 616)$ are allowed to react with $9.4 \times 10^{-8} \mathrm{mbar}$ acetone and (b) mass selected $\mathrm{Fe}(\mathrm{III})$-heme $\left(\left[\mathrm{CH}_{3}\right]_{2} \mathrm{CO}\right)^{+}$ions $(\mathrm{m} / \mathrm{z}$ 674) are allowed to react (dissociate) in the presence of acetone at the same pressure. The unvarying ratio of ion intensities that is observed when the kinetic progress of the reaction is over is considered evidence for an association equilibrium. 
Table 5. Summary of rate and equilibrium data for the reactions of $\mathrm{Fe}(\mathrm{III})$-heme ${ }^{+}$with ligands (L) leading to a constant intensity ratio for the $\mathrm{Fe}(\mathrm{III})-$ heme $^{+}$ion and the adduct ion

\begin{tabular}{lcccc}
\hline \multicolumn{1}{c}{$\mathrm{L}$} & $\mathrm{K}_{1} / 10^{9 \mathrm{a}}$ & $-\Delta \mathrm{G}_{1}{ }^{\text {ob }}$ & $\left(\mathrm{k}_{\text {exp, } 1} / \mathrm{k}_{-1}\right) / 10^{9 \mathrm{c}}$ & $\left(\mathrm{k}_{\text {exp,1 }} \mathrm{KF}^{\mathrm{K}} \mathrm{k}_{-1}{ }^{\mathrm{KF}}\right) / 10^{9 \mathrm{c}}$ \\
\hline \hline $\mathrm{CH}_{3} \mathrm{OH}$ & $3.1 \pm 0.5$ & $13.11 \pm 0.1$ & $3.1 \pm 1.3$ & $2.7 \pm 0.5$ \\
$\mathrm{CH}_{3} \mathrm{CN}$ & $8.8 \pm 1.3$ & $13.74 \pm 0.1$ & $14.1 \pm 9$ & $11 \pm 4$ \\
$\left(\mathrm{CH}_{3}\right)_{2} \mathrm{CO}$ & $50.3 \pm 7.2$ & $14.78 \pm 0.1$ & $17.1 \pm 8$ & $38 \pm 17$ \\
\hline
\end{tabular}

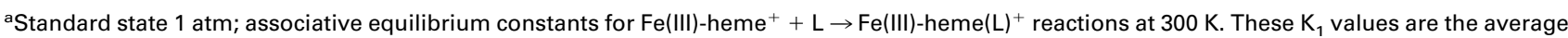
calculated from the data (last column in Table 2) obtained from the constant ion intensity ratios at equilibrium and the ligand pressure.

$\mathrm{b}_{-} \Delta \mathrm{G}_{1}^{\circ}=\mathrm{RT} \ln \mathrm{K}_{1}$.

In units of atm $^{-1}$.

pounds) of cigarette smoke [43]. The rate coefficients in Table 1 show that $\left(\mathrm{CH}_{3}\right)_{2} \mathrm{NNO}$ is kinetically favored with respect to NO in the association to gaseous Fe(III)heme $^{+}$ions. Conversely, NO is by far more efficient than $\mathrm{O}_{2}$ or $\mathrm{CO}$, which appear unreactive within the accessible experimental conditions. This finding is consistent with the order of binding energies of $\mathrm{Fe}$ (II)-heme $(\mathrm{FeP})$ complexes, FeP-O $2\left(9 \mathrm{kcal} \mathrm{mol}^{-1}\right)<\mathrm{FeP}-\mathrm{CO}(26$ $\left.\mathrm{kcal} \mathrm{mol}^{-1}\right)<\mathrm{FeP}-\mathrm{NO}\left(35 \mathrm{kcal} \mathrm{mol}^{-1}\right)$ as derived by DFT calculations [44].

The thermodynamic parameters for ligand binding depend on the electronic and structural features of the cation. It is useful to refer to the proton as the prototypical cation. Table 6 gives the gas-phase basicity toward the proton (GB) [24] of the ligands and Figure 9 shows the HCB values for complex formation with Fe(III)-heme ${ }^{+}$ plotted versus the GB values of the ligands [45, 46]. Notably, the gas-phase HCB values are smaller than the corresponding GBs and cover a much narrower range in the energy scale. This behavior is primarily due to the smaller size of the proton besides the obviously different bonding features in the protonated species $\left(\mathrm{LH}^{+}\right)$with respect to the $\mathrm{Fe}(\mathrm{III})$-hemeL ${ }^{+}$complexes.

Finally, NO, an odd-electron species displaying unique binding properties to heme-type centers, falls outside the HCB/GB range of Figure 9 because of its

Table 6. Free energy changes for gas-phase ligand binding toward $\mathrm{H}^{+}$and $\mathrm{Fe}(\mathrm{III})$-heme ${ }^{+}$

\begin{tabular}{lcc}
\hline \multicolumn{1}{c}{$\mathrm{L}$} & $\mathrm{GB}^{\mathrm{a}}$ & $\mathrm{HCB}^{\mathrm{b}}$ \\
\hline \hline $\mathrm{CH}_{3} \mathrm{OH}$ & 173.2 & 13.1 \\
$\mathrm{CH}_{3} \mathrm{CN}$ & 179.0 & 13.7 \\
$\left(\mathrm{CH}_{3}\right)_{2} \mathrm{CO}$ & 186.9 & 14.6 \\
$\mathrm{CH}_{3} \mathrm{CO}_{2} \mathrm{CH}_{3}$ & 189.0 & 14.8 \\
$\mathrm{NO}$ & 120.8 & 16.1 \\
$\mathrm{NH}_{3}$ & 195.7 & 16.6 \\
$\left(\mathrm{CH}_{3}\right)_{2} \mathrm{~S}$ & 191.5 & 16.9 \\
$\mathrm{Tetrahydrofuran}_{\left(\mathrm{CH}_{3}\right)_{2} \mathrm{~N}-\mathrm{NO}}$ & 189.9 & 18.1 \\
$\mathrm{CH}_{3} \mathrm{NH}$ & $203.0^{\circ}$ & 18.9 \\
$\left(\mathrm{CH}_{3} \mathrm{O}\right)_{2} \mathrm{PO}(\mathrm{H})$ & 206.6 & 21.2 \\
$\mathrm{Pyridine}^{\mathrm{c}}$ & 206.1 & 22.7 \\
$\mathrm{CH}_{3} \mathrm{CON}(\mathrm{CH})_{2}$ & 214.7 & 24.1 \\
$\left(\mathrm{CH}_{3} \mathrm{O}\right)_{3} \mathrm{PO}$ & 209.6 & 24.8 \\
\hline
\end{tabular}

${ }^{a}$ Gas phase basicities (GB) in $\mathrm{kcal} \mathrm{mol}^{-1}$, at $298 \mathrm{~K}$; data from ref [45], unless noted otherwise.

bIn kcal mol${ }^{-1}$, at $300 \mathrm{~K}$. Estimated error $\pm 0.2 \mathrm{kcal} / \mathrm{mol}$ for relative values, and $\pm 1.0 \mathrm{kcal} / \mathrm{mol}$ for absolute values.

${ }^{\mathrm{c}} \operatorname{Ref}[46]$. exceptional affinity for $\mathrm{Fe}(\mathrm{III})-$ heme $^{+}$in spite of its low GB. A partial charge-transfer character of the NO complex may account for this behavior. Indeed, recent mechanistic studies on the reversible binding of NO to the ferriheme center of aqueous metmyoglobin have shown that a partial charge transfer from $\mathrm{NO}$ to $\mathrm{Fe}(\mathrm{III})$ occurs during formation of a linear adduct, which may be formally depicted as $\mathrm{Fe}(\mathrm{II})-\mathrm{NO}^{+}$[47]. However, the reverse process, namely $\mathrm{NO}$ dissociation, is found to involve homolysis of the Fe-NO bond releasing neutral NO. Similarly, it is found in the present study that even compounds known to behave as powerful $\mathrm{NO}^{+}$acceptors in the gas phase, such as pyridine and dimethylacetamide [48], fail to show any evidence of $\mathrm{NO}^{+}$transfer from gaseous $\mathrm{Fe}(\mathrm{III})$-heme(NO) ${ }^{+}$.

\section{Conclusions}

A variety of ligands have been observed to associate to gaseous Fe(III)-heme ${ }^{+}$ions. The ligands were chosen to represent several functionalities that may interact with heme-based prosthetic groups. The reaction efficiencies show a positive trend with the binding free energy, namely the $\mathrm{HCB}$ value of the ligand $\left(-\Delta \mathrm{G}_{1}{ }^{\circ}\right)$. In turn, a correlation between $\mathrm{HCBs}$ and GBs of the ligands suggests that similar effects play a role when a lone pair donor ligand binds to a proton or to Fe(III)-heme ${ }^{+}$. The observed positive trend is qualitative though, with

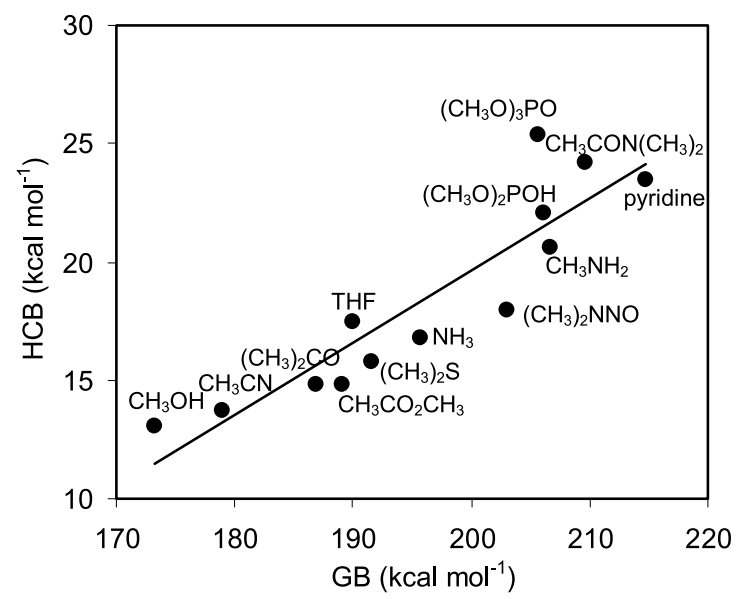

Figure 9. General correlation between $\mathrm{Fe}(\mathrm{III})-\mathrm{heme}^{+}$cation basicities ( $\mathrm{HCB}$, equal to $-\Delta \mathrm{G}_{1}{ }^{\circ}$ for the ligand association reaction) and gas phase basicity toward the proton $(\mathrm{GB})$ values. 
significant deviations from the straight line drawn to fit the experimental data. Upward deviations in the correlation of Figure 9 suggest that harder ligands are preferentially bound by $\mathrm{Fe}(\mathrm{III})$-heme ${ }^{+}$. For example, THF is favored with respect to methylacetate [49]. Also, ion-dipole contributions to the coordinative bonding can be relevant especially for those ligands endowed with high dipole moment [50]. This factor may account for the high HCB of dimethylacetamide $(\mu=3.8 \mathrm{D})$ and of trimethylphosphate $(\mu=3.0 \mathrm{D})$ with respect to the relatively low HCB of the more basic pyridine $(\mu=2.2$ D). Ion-permanent dipole interactions have been suggested to contribute significantly to the bonding of metalloporphyrin ions with nitrogen bases in a related study [51] where the binding of four metalloporphyrin ions, including $\mathrm{Fe}(\mathrm{III})$-heme ${ }^{+}$, with amines has been investigated by energy resolved collision induced dissociation and by ion molecule reactions in a quadrupole ion trap mass spectrometer. The failure to observe any clear correlation with the proton affinity of the sampled nitrogen ligands was ascribed to the role played by this effect.

NO stands out as superior ligand towards Fe(III)heme $^{+}$, displaying exceptionally high reactivity with respect to its low proton basicity. This finding is in line with the paramount role of the interaction of $\mathrm{NO}$ with heme-type complexes in biological environments.

\section{Acknowledgments}

The authors gratefully acknowledge financial support by the Italian Ministero dell'Istruzione, dell'Università e della Ricerca (PRIN 2003) and by the Università di Roma "La Sapienza."

\section{References}

1. Kaim, W.; Schwederski B. Bioinorganic Chemistry: Inorganic Elements in the Chemistry of Life; Wiley: Chichester, 1994, pp 82-127.

2. Lippard, S. J.; Berg, J. M. Principles of Bioinorganic Chemistry; University Science Books: Mill Valley, CA, 1994, pp 243-253, 284-291, 302-311, 329-333.

3. Loew, G. H.; Harris, D. L. Chem. Rev. 2000, 100, 407-419.

4. Lombardi, A.; Nastri, F.; Pavone, V. Chem. Rev. 2001, 101, 3165-3189.

5. Marshall, A., G.; Hendrickson, C. L.; Jackson, G. S. Mass Spectrom. Rev. 1998, 17, 1-35.

6. McMahon, T. B. Int. J. Mass Spectrom. 2000, 200, 187-199.

7. Gapeev, A.; Dunbar, R. C. J. Am. Chem. Soc. 2001, 123, $8360-8365$.

8. Operti, L.; Rabezzana, R. Mass Spectrom. Rev. 2003, 22, 407428.

9. Sharpe, P.; Richardson, D. E. Coord. Chem. Rev. 1989, 93, 59-85.

10. Eller, K.; Schwarz, H. Chem. Rev. 1991, 91, 1121-1177.

11. Freiser, B. S. Acc. Chem. Res. 1994, 27, 353-360.

12. Beauchamp, J. L., Van Koppen, P. A. M. Fundamental Gas phase Studies of the Mechanism and Thermochemistry of Organometallic Reactions. NATO ASI Series, Series C: Mathematical and Physical Sciences 1992, 367, 287-320.

13. Fenn, J. B.; Mann, M.; Meng, C. K.; Wong, S. F.; Whitehouse, C. M. Science 1989, 246, 64-71.
14. In Electrospray Ionization Mass Spectrometry, Fundamentals, Instrumentation, and Applications; Cole, R. B., Ed.; Wiley: New York, 1997.

15. Kebarle, P. J. Mass Spectrom. 2000, 35, 804-817.

16. Irikura, K. K.; Beauchamp J. L. J. Am. Chem. Soc. 1991, 113, 2767-2768.

17. Chen, H. L.; Hagan, T. E.; Groh, S. E.; Ridge, D. P. J. Am. Chem. Soc. 1991, 113, 9669-9670.

18. Hendrickson, C. L.; Emmett, M. R. Annu. Rev. Phys. Chem. 1999, 50, 517-536.

19. Wolak, M.; van Eldik, R. Coord. Chem. Rev. 2002, 230, 263-282.

20. Scheidt, W. R.; Ellison, M. K. Acc. Chem. Res. 1999, 32, 350-359.

21. Ryzhov, V.; Dunbar, R. C. J. Am. Soc. Mass Spectrom. 1999, 10, 862-868.

22. Fridgen, T. D.; McMahon, T. B. J. Phys. Chem. A 2002, 106, 1576-1583.

23. Chen, O.; Groh, S.; Liechty, A.; Ridge, D. P. J. Am. Chem. Soc. 1999, 121, 11910-11911.

24. Meot-Ner (Mautner), M. Int. J. Mass Spectrom. 2003, 227, 525-554.

25. Meot-Ner, M. In Gas Phase Ion Chemistry; Bowers, M. T. Ed.; Academic Press: New York, 1979; Vol. I, Chap. VI, pp 197-271.

26. Bartmess, J. E.; Georgiadis, R. M. Vacuum 1983, 33, 149-153.

27. Schröder, D.; Schwarz, H.; Clemmer, D. E.; Chen, Y.; Armentrout, P. B.; Baranov, V. I.; Bohme, D. K. Int. J. Mass Spectrom. Ion Processes 1997, 161, 175-191.

28. Su, T.; Chesnavich, W. J. J. Chem. Phys. 1982, 76, 5183-5185.

29. Dunbar, R. C. Mass Spectrom. Rev. 1992, 11, 309-339.

30. Fisher, J. J.; McMahon, T. B. Int. J. Mass Spectrom. Ion Processes 1990, 100, 701-717.

31. Dunbar, R. C. Int. J. Mass Spectrom. Ion Processes 1997, 160, 1-16.

32. Stöckigt, D.; Hrušák, J.; Schwarz, H. Int. J. Mass Spectrom. Ion Processes 1995, 149/150, 1-11.

33. McEwan, M. J., In Advances in Gas Phase Ion Chemistry; Adams, N.; Babcock, L. M., Eds.; In JAI Press: London, 1992; Vol. I, pp $1-42$.

34. Büker, H.-H.; Grützmacher, H.-F.; Crestoni, M. E.; Ricci, A. Int. J. Mass Spectrom. Ion Processes 1997, 160, 167-181.

35. Shen, N. Z.; Pope, R. M.; Dearden, D. V. Int. J. Mass Spectrom. 2000, 196, 639-652.

36. Combariza, M. Y.; Vachet, R. W. J. Am. Soc. Mass Spectrom. 2004, 15, 1128-1135.

37. Dunbar, R. C.; McMahon, T. B. Science 1998, 279, 194-197.

38. Dunbar, R. C. Mass Spectrom. Rev. 2004, 23, 127-158.

39. Price, W. D.; Williams, E. R. J. Phys. Chem. A 1997, 101, $8844-8852$

40. Appel, K. E., Ruf, H. H; Mahr, B.; Schwarz, M.; Rickart, R.; Kunz, W. Chem. Biol. Interact. 1979, 28, 17-33.

41. Richter-Addo, G. B. Acc. Chem. Res. 1999, 32, 529-536.

42. Hetch, S. S. Proc. Soc. Exp. Biol. Med. 1997, 216, 181-191.

43. Deliconstantinos, G.; Villiotou, V.; Stavidres, J. C. Anticancer Res. 1994, 14, 2717-2726.

44. Rovira, C.; Kunc, K.; Hutter, J.; Ballone, P.; Parrinello, M. J. Phys. Chem. 1997, 101, 8914-8925.

45. Hunter, E. P., Lias; S. G. In NIST Chemistry Webbook, NIST Standard Reference Database Number 69; Linstrom, P. J.; Mallard, W. G., Eds.; National Institute of Standards and Technology: Gaithersburg, MD, 2003, http://webbook.nist.gov.

46. Crestoni, M. E., Fornarini, S. J. Mass Spectrom. 2004, in press.

47. Laverman, L. E.; Wanat, A.; Oszajca, J.; Stochel, G.; Ford, P. C.; van Eldik, R. J. Am. Chem. Soc. 2001, 123, 285-293.

48. Cacace, F.; de Petris, G.; Pepi, F. Proc. Natl. Acad. Sci. U.S.A. 1997, 94, 3507-3512.

49. Pearson, R. G. Inorg. Chem. 1988, 27, 734-740.

50. Deng, H.; Kebarle, P. J. Am. Chem. Soc. 1998, 120, 2925-2931.

51. Hayes, L. A.; Chappell, A. M.; Jellen, E. E.; Ryzhov, V. Int. J. Mass Spectrom. 2003, 227, 111-120. 